\title{
Towards Zero Solid Waste in the Sedimentary Phosphate Industry: Challenges and Opportunities
}

\author{
Yassine Taha ${ }^{1, *(\mathbb{D}}$, Abdellatif Elghali ${ }^{2}(\mathbb{D})$, Rachid Hakkou ${ }^{1,3}$ and Mostafa Benzaazoua ${ }^{1}(\mathbb{D}$ \\ 1 Mining Environment and Circular Economy (EMEC), Mohammed VI Polytechnic University, Lot 660, \\ Hay Moulay Rachid, Ben Guerir 43150, Morocco; r.hakkou@uca.ac.ma (R.H.); \\ Mostafa.benzaazoua@um6p.ma (M.B.) \\ 2 Geology and Sustainable Mining Department, Mohammed VI Polytechnic University, Lot 660, \\ Hay Moulay Rachid, Ben Guerir 43150, Morocco; Abdellatif.elghali@um6p.ma \\ 3 IMED-Laboratory, Faculté des Sciences et Techniques, Université Cadi Ayyad, BP 549, \\ Marrakech 40000, Morocco \\ * Correspondence: yassine.taha@um6p.ma; Tel.: +212-525-072-867
}

check for updates

Citation: Taha, Y.; Elghali, A.; Hakkou, R.; Benzaazoua, M. Towards Zero Solid Waste in the Sedimentary Phosphate Industry: Challenges and Opportunities. Minerals 2021, 11, 1250. https://doi.org/10.3390/ $\min 11111250$

Academic Editors: Alexander Mikhailovich Kalinkin and Carlito Tabelin

Received: 12 October 2021

Accepted: 8 November 2021

Published: 10 November 2021

Publisher's Note: MDPI stays neutral with regard to jurisdictional claims in published maps and institutional affiliations.

Copyright: (c) 2021 by the authors. Licensee MDPI, Basel, Switzerland. This article is an open access article distributed under the terms and conditions of the Creative Commons Attribution (CC BY) license (https:/ / creativecommons.org/licenses/by/ $4.0 /)$.

\begin{abstract}
The phosphate industry produces huge volumes of waste (hundred million tons per year). These wastes are generally surface landfilled, leading to significant environmental impacts and a large footprint. The current practices of phosphate waste management, the typology of the waste streams and their characteristics, and finally their potential applications are reviewed. All the waste streams generated during the life cycle of phosphoric acid production going from the extraction of phosphate rock to its enrichment and transformation are considered. Great circularity opportunities have been identified and they aim (i) to recover the residual phosphorus and other critical minerals and metals, and (ii) to consider phosphate wastes as alternative resources in the civil engineering and building sectors. The purpose is to shift from linear thinking to circular thinking where synergy between different mining and other industries is highly encouraged. By doing so, opportunities to safeguard natural resources and to minimize the environmental and societal impacts are limitless. However, many challenges are still limiting this shift: economic and technical constraints, societal and policy-makers' awareness, regulation harmonization and finally knowledge gaps. More efforts and investment in research and development are still required to reach the zero-waste target.
\end{abstract}

Keywords: near-zero-waste; circular economy; phosphate mine wastes; waste management; waste rock; tailings; phosphogypsum; construction materials

\section{Introduction}

The phosphate mining industry is vital for worldwide food security. Phosphorus is used mainly in the fields of agriculture, medicine, food, chemicals, etc. The largest phosphate deposits (50 billion tons) are located in Morocco (Figure 1), while the four main producers are China, Morocco, the USA and Russia (Figure 2) [1]. It is estimated that more than 270 million metric tons of phosphate rock was produced during 2017 [1], which represents an increase of more than $45 \%$ in comparison to 2000 . After this production peak in 2017, production has slightly decreased to 223 million metric tons of phosphate rock in 2020 [1]. This is due mainly to the production decrease in China, shifting from 140 million tons (2017) to less than 95 million tons (2020) [1].

Phosphate rock may occur in different mineralization forms: sedimentary ores, igneous ores, metamorphic ores, and biogenic ores. Sedimentary phosphate deposits are principally composed of apatite and associated gangue minerals (calcite, dolomite, quartz, and clays) and metals (fluoride, cadmium, arsenic, uranium, and mercury). With increasing demand due to global population growth, the high-grade phosphate deposits are being depleted and the need to explore low-grade phosphate ores is growing. The current phosphate supply chain includes the extraction of phosphate rocks (mostly open 
pit), beneficiation (screening, desliming, and froth flotation), chemical transformation (wet phosphoric acid process), and phosphate fertilizer production (different kinds) [2]. As a result, the beneficiation of these low-grade ores will require additional water sources, energy, and chemicals, and will lead to the production of high volumes of solid wastes with potential environmental impacts.

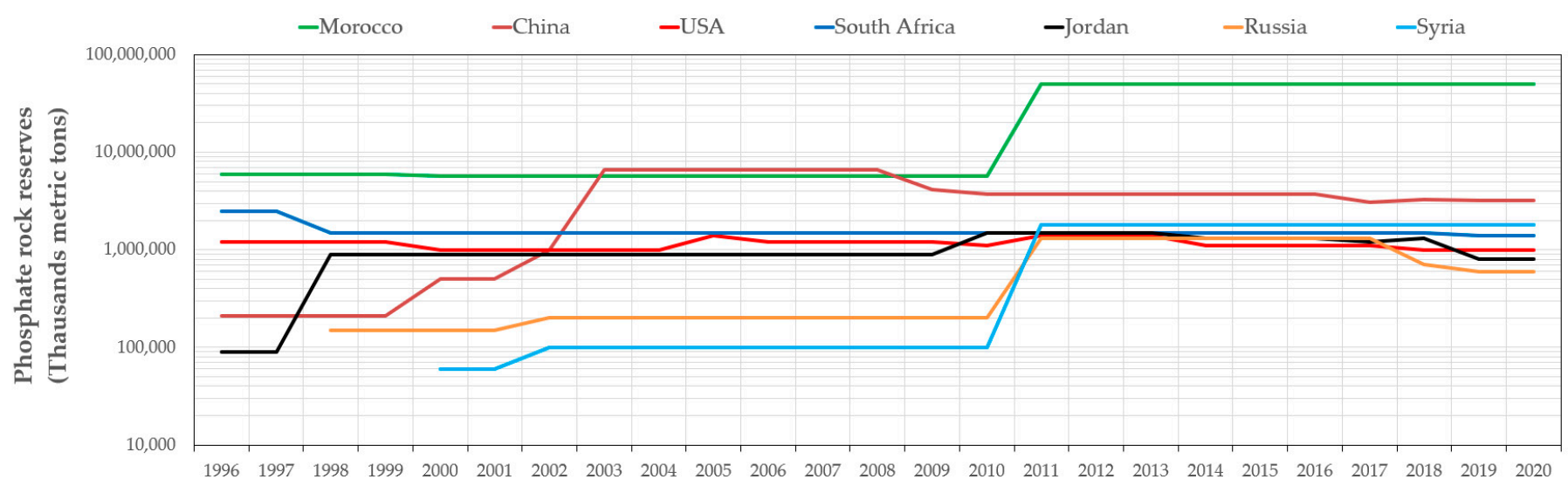

Figure 1. Global phosphate rock reserves (Source: data compiled from USGS database, 1994-2020).

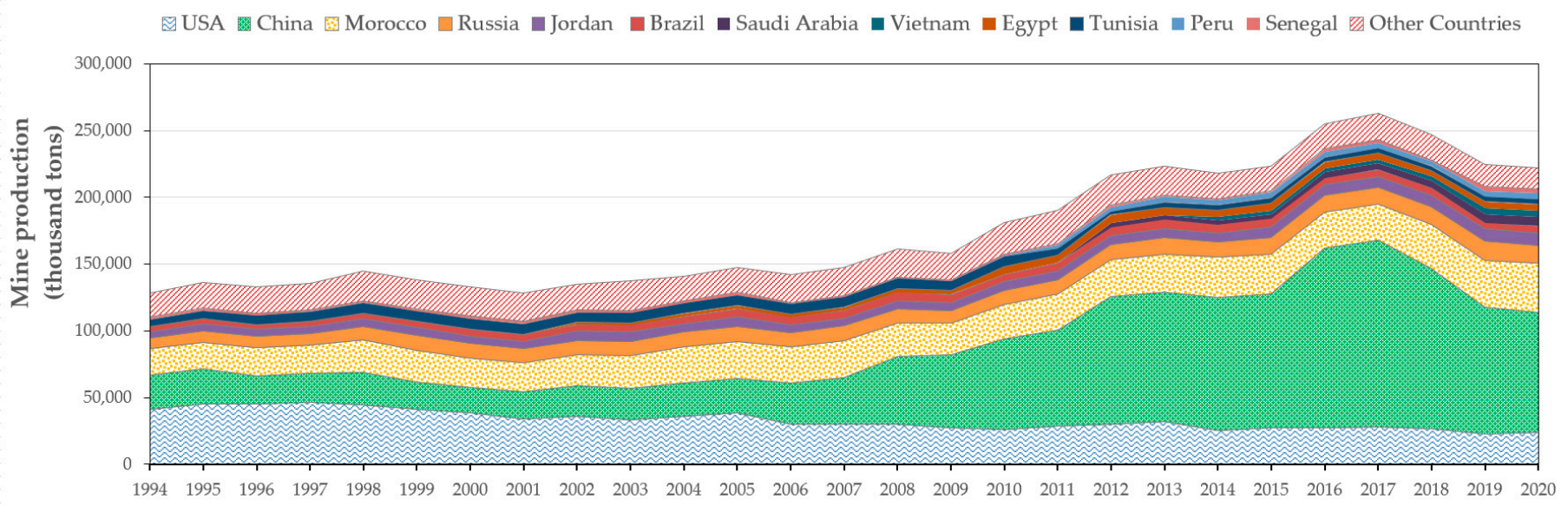

Figure 2. Phosphate rock production by country. Source: data compiled from USGS database, 1994-2020.

The phosphate mining industry, as it is the case for almost mining industries, has followed a linear consumption and production model, where wastes are continuously produced and stored in waste rock dumps and tailings storage facilities. The volume of these wastes is increasing due to the growing demand for phosphorus in different sectors [3]. The stripping ratio is an informative tool to estimate roughly the volume of waste to be produced. If we consider a stripping ratio between 3:1 and 12:1, for $260 \mathrm{Mt}$ of phosphate rock production, between $780 \mathrm{Mt}$ and $3120 \mathrm{Mt}$ of waste rock was produced in 2017 alone. To this, we should add the tailings from beneficiation processing and phosphogypsum from the chemical plants. These wastes are generally considered as a source of pollution and additional management costs (rehabilitation and restoration).

With the depletion of nonrenewable resources and high-grade ores, the difficult treatment of low-grade and complex ores, and the challenge of increasing waste generation, major focus is currently given to implementing a circular economy approach in the global mining sector. The goal is to strive towards circular supply chains rather than the current linear extractive models. In other words, the purpose is to close loops to simultaneously safeguard natural resources and to minimize the environmental and societal impacts of this industry. Novel sustainable and ecofriendly strategies are required to minimize waste generation, to optimize energy consumption, to decrease the possible environmental 
impacts on air and water, and finally to encourage the reuse of generated wastes. It was reported that a circular economy approach could generate an estimated material cost savings of 1 trillion USD by 2025 [4]. Kinnunen [5] reported that the European commission has estimated that 600 billion EUR can be saved for EU businesses and 580,000 jobs can be created by 2030 as a result of circular economy thinking. In the academic world, many research funding project calls were launched worldwide in the recent decade to tackle this big challenge. For example, in Europe, a call titled "Waste: A resource to recycle, reuse and recover raw materials (H2020-WASTE-2014-2015)" [6] was launched in 2015 with a budget of 54 million EUR. In 2021, another call for research titled "Raw materials for the sustainable development and the circular economy" [7] was launched by a pan-European network of research funding organizations, supported by EU Horizon 2020 with a budget of 19 million EUR. The aim of these project calls is to finance collaborative research and innovative mining projects related to, among others, circular design for resource efficiency, recycling, and reuse of end-of-life products. Several review papers were recently published to highlight the importance of the circular economy [8-11].

The implementation of the circular economy concept in the mining industry is still in the initial stages. The focus of this manuscript is to draw some responses to the challenges faced by waste generation in the phosphate mining industry, one of the largest waste streams in the global mining sector): How can phosphate wastes be returned to the process as an input rather than being disposed of or becoming a pollutant? How can phosphate wastes build capital rather than decrease it? What if the wastes of today become the resources of tomorrow? Is it possible to shift from linear to circular thinking? What are the main challenges and opportunities? How can these novel management strategies be adopted by the phosphate industry? Responses to all these questions are developed further in the following sections.

This review aims to: (i) present the different kinds and characteristics of solid wastes produced during the extraction, beneficiation, and transformation of sedimentary phosphate ores, (ii) present the environmental impacts related to these wastes, (iii) highlight current management methods, and (iv) present the potential opportunities related to circular economy thinking.

\section{Methodology}

This work is based on an integrative and critical literature review in which only peerreviewed scientific articles were evaluated. It aims to identify the main conceptual gaps in phosphate waste management and to present novel perspectives. Research papers were selected based on a careful analysis of the title, keywords, and abstract. The content of the selected papers was evaluated to identify their relevance and suitability to the objectives of this article. The following keywords were used in the search: sedimentary phosphate, phosphate byproducts, phosphate clay sludge, phosphate tailings, phosphate waste rock, phosphogypsum, and phosphate mine waste. Scopus and Google Scholar were the main databases used. The study covered all the published papers in the period between 1970 and 2020 and a focus was given to the recovery of critical raw materials (phosphate, REE, $\mathrm{U}$, etc.) and use of waste outside the mine site. Papers dealing with waste water sludges as a source of organic phosphorus were not considered. Only solid wastes coming from the exploitation of sedimentary phosphate deposits were targeted in this study. It was observed that the number of published papers in the recent 50 years showed an increasing trend (Figure 3). This indicates that the concerns for such a topic are receiving greater attention. The majority of research studies focused on the physical, chemical, mineralogical, and radiological characterizations of different kinds of phosphate wastes. The environmental impacts of wastes and their reuse, recycling, valorization, and utilization in other sectors such as construction and building materials, agriculture, water treatment were evaluated. 


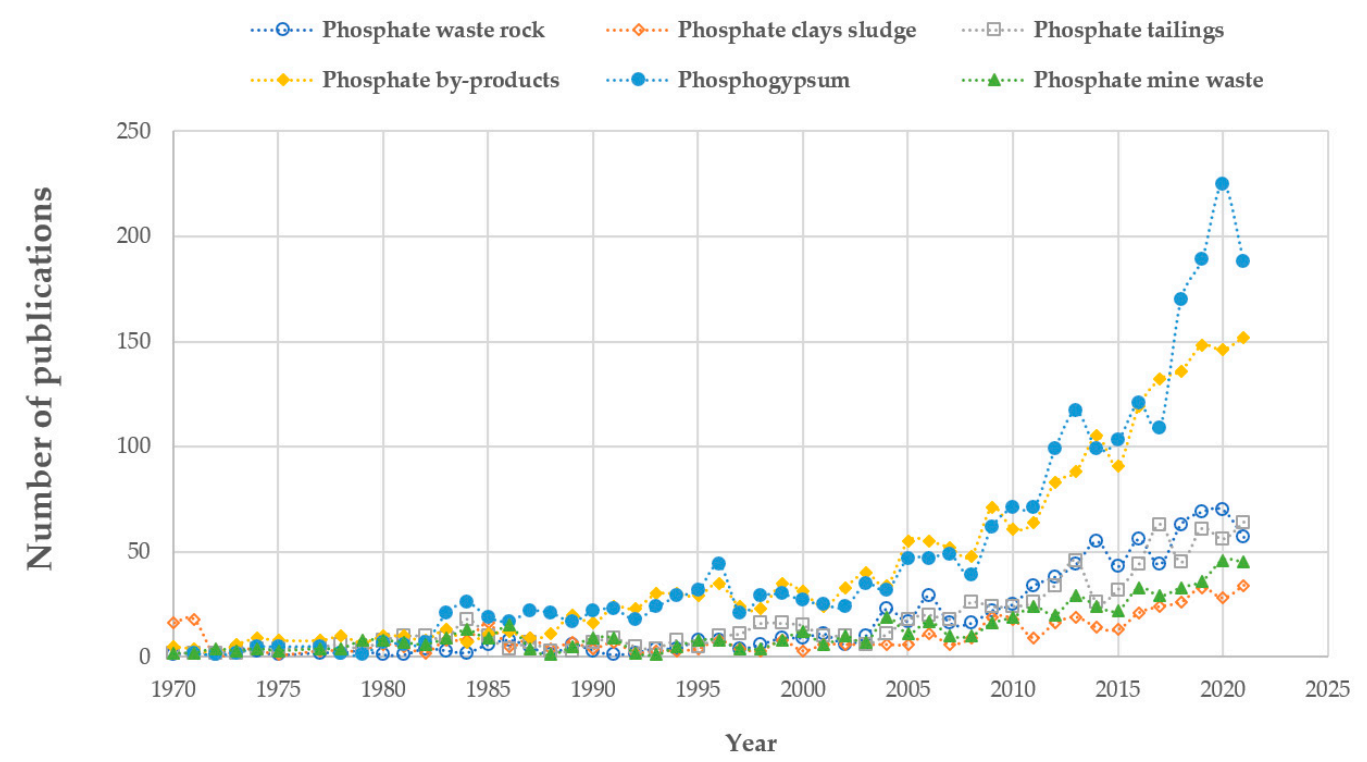

Figure 3. Number of publications dealing with the different phosphate waste streams in the last 50 years (data gathered from Scopus).

\section{Phosphate Waste Streams and Characteristics}

Only solid wastes are considered in this paper. Liquid and gaseous emissions are not considered. To have an idea about the properties of solid waste material, it is important to understand their source and processes. Seven major waste streams are recognized and listed in Table 1. Three waste categories are generated during mining operations, three others during beneficiation, and one during the chemical transformation.

Table 1. Main solid waste streams in the phosphate supply chain.

\begin{tabular}{lll}
\hline Mining/Extraction Wastes & Beneficiation Wastes & Transformation Wastes \\
\hline Exploitation waste rock & Beneficiation waste rock & Phosphogypsum \\
(overburden and interlayers) & Phosphate sludge & \\
$\begin{array}{l}\text { Destoning waste rock } \\
\text { Screening waste rock }\end{array}$ & Froth tailings & \\
\hline
\end{tabular}

Each waste is the result of a particular step in the mining, beneficiation and transformation process. These wastes differ because of various factors: the geological setting of the ore, its depth and geometry, the grade of the phosphate minerals, and the extraction and treatment process. Figure 4 highlights the different waste streams in a phosphate supply chain.

\subsection{Mining/Extraction Operations Waste Streams}

The most common steps during phosphate mining are the removal of the topsoil and overburden and the extraction of phosphate layers through open pit mining activities. Several methods are used to process phosphate ores [12]. Open-pit mining methods are generally known to generate more waste rock than underground mining. The stripping ratio is an important parameter in phosphate mining not only to estimate the costs of extraction but also to predict the volume of waste produced during mining operations. This ratio could reach a maximum of 11:1 depending on the phosphate orebody thickness and depth [13]. A ratio of 11:1 means that more than 11 tons of waste rock would be produced to extract 1 ton of phosphate rock.

After blasting, large electric walking draglines are the most widely used mining technique for the removal of the overburden and the preparation for excavation of the phosphate ore $[12,14]$. The overburden and nonphosphatic layers are mined using a 
dragline machine and deposited directly as a mixed waste stream called "exploitation waste rock". The extracted phosphate (mixed with gangue rocks) is then sent to the crusher and sieved to remove the coarse particles, generally $>60 \mathrm{~mm}$, creating a second waste stream called "destoning waste rock". The passing material is then sieved to remove particles generally $>10 \mathrm{~mm}$, creating a third waste stream called "screening waste rock". Those wastes are surface landfilled close to the mine site to avoid high transport costs.

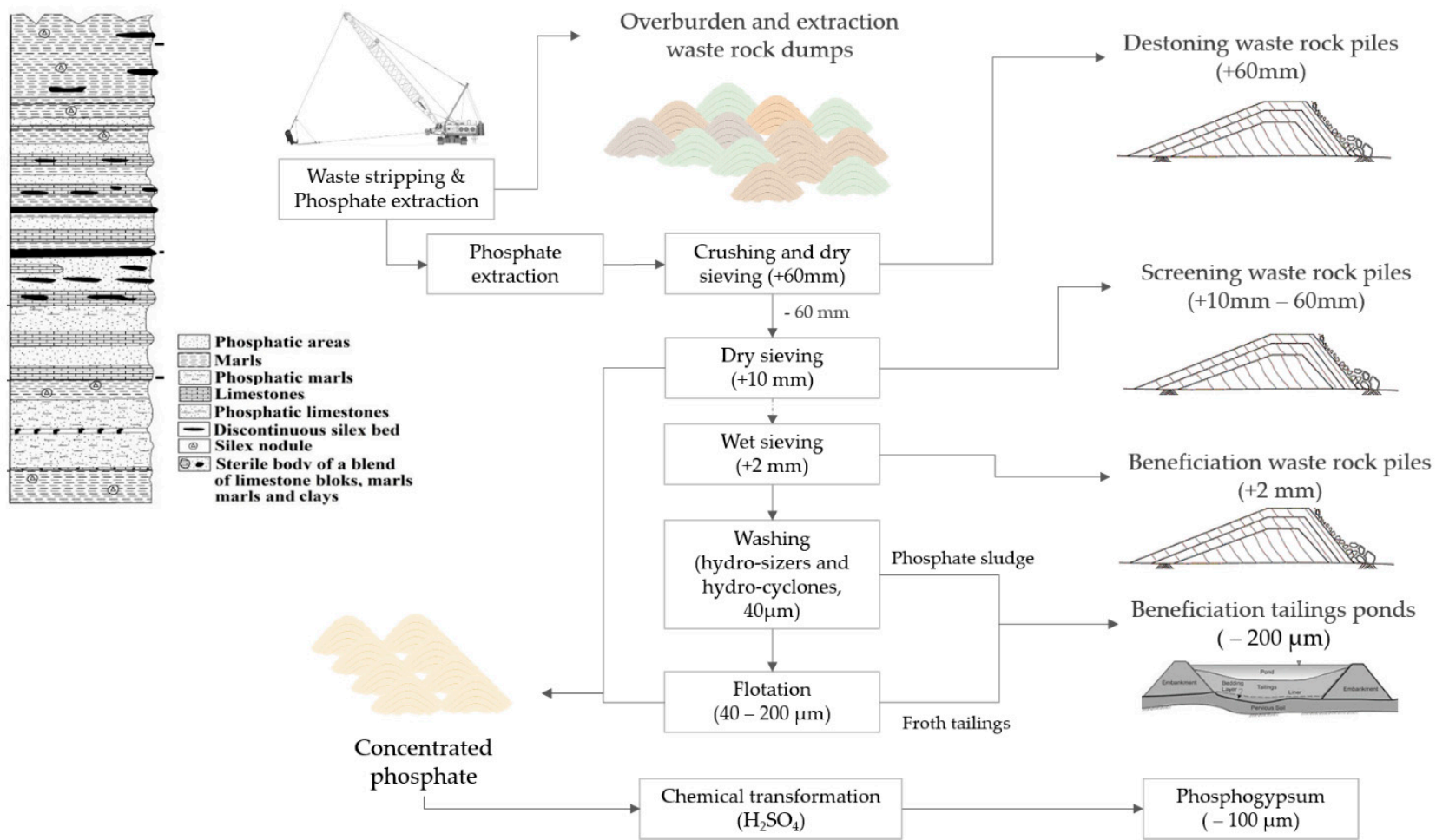

Figure 4. A general flowsheet of the different waste streams from the mining, beneficiation, and transformation of sedimentary phosphate ore.

The overburden and waste rock are highly heterogeneous and mainly composed of clays, limestones, marls, flintstone, sand, and residual phosphate minerals [2]. Due to this heterogeneity, the management and reuse of these wastes is complex and requires the use of more sophisticated techniques such as ore sorting. Therefore, for a successful mine closure and sustainable rehabilitation, it is important to consider the heterogeneity of the overburden layers and the excavation method in the early stages of the mine project development plans.

\subsection{Beneficiation Processing Waste Streams}

Phosphate beneficiation is generally used to upgrade the apatite content by removing the low-grade ores and gangue minerals (clays, limestones, etc.). Mixing, screening, washing, and flotation are the main processes used in the phosphate beneficiation plants in Morocco [12]. Upon arrival at the beneficiation plants, the low- and medium-grade phosphate ores undergo a wet sieving around $2 \mathrm{~mm}$, creating a fourth waste stream called "beneficiation waste rock". The removed materials are washed and landfilled in waste rock piles. After phosphate desliming in hydrosizers and hydrocyclones, a very fine and silty material is generated, called "phosphate sludge $-40 \mu \mathrm{m}$ ". After flotation processing, limestone and silicate minerals are floated together using ester and amine collectors (reverse cationic flotation) creating a sixth waste stream called "froth tailings". Currently, froth tailings and phosphate sludges are mixed and stored in beneficiation tailings ponds over an area of several dozen hectares. The disposal of these tailings can present many risks related to the stability of the ponds. 
The storage of the phosphate sludge and froth tailings is considered problematic due to the large environmental footprint of the tailing ponds, the large volumes of waste, and the associated restoration costs. The reclamation and restoration of these tailings ponds is generally not easily attainable due to the poor physical properties, low hydraulic conductivity, and heavy metal content [15]. It is estimated that one ton of phosphate sludge (froth tailings and clays) is generated for each ton of final phosphate product [16].

The chemical and mineralogical compositions of these sludges and tailings are highly variable and depend on the geological context of the extracted ores. The major minerals found in Moroccan phosphate beneficiation wastes include quartz $\left(\mathrm{SiO}_{2}\right)$, clays (montmorillonite $\left(\mathrm{Si}_{8} \mathrm{Al}_{3.5} \mathrm{Mg}_{0.5} \mathrm{O}_{20}(\mathrm{OH})_{4}\right)$, illite $\left((\mathrm{K}, \mathrm{Al}, \mathrm{Mg}, \mathrm{Fe})_{2}(\mathrm{Si}, \mathrm{Al})_{4} \mathrm{O}_{10}\left[(\mathrm{OH})_{2},\left(\mathrm{H}_{2} \mathrm{O}\right)\right]\right)$, and palygorskite $\left.\left(\left(\mathrm{Mg}, \mathrm{Al}_{2}\right)_{2} \mathrm{Si}_{4} \mathrm{O}_{10}(\mathrm{OH}) \cdot 4\left(\mathrm{H}_{2} \mathrm{O}\right)\right)\right)$, limestones (dolomite $\left(\mathrm{CaMg}\left(\mathrm{CO}_{3}\right)_{2}\right)$ and calcite $\left.\left(\mathrm{CaCO}_{3}\right)\right)$, and residual phosphate minerals (fluorapatite $\left(\mathrm{Ca}_{5}\left(\mathrm{PO}_{4}\right)_{3} \mathrm{~F}\right)$ ). These findings are in accordance with the results from other studies [17-19]. The proportion of these minerals in beneficiation wastes varies significantly among sites. Beneficiation plants often mix different phosphate ores from different sources in response to customer specifications (i.e., impurities content such as $\mathrm{Cd}, \mathrm{MgO}$, etc.).

Clays are mostly removed because they can affect the performance of the flotation process by coating the surface of phosphate minerals (known as slime-coatings) and increasing reagent consumption. Carbonate minerals are removed to improve the quality of the phosphate rock and to avoid any downstream processing issues, particularly during the production of phosphoric acid. These issues can include increased sulfuric acid consumption (high production costs) and low phosphogypsum filtration performance due to the increased fluid viscosity, mainly due to the presence of dolomite [2]. However, it is important to note that the removal of dolomite by flotation is reported to be difficult, as it presents similar surface properties as apatite [20-22]. The same problem was also reported with calcite $[23,24]$. These carbonates are removed using flotation, or sometimes calcination at high temperatures $\left(700-850^{\circ} \mathrm{C}\right)$ if the flotation processing is insufficient. The removal of quartz by flotation is crucial to avoid equipment erosion, high filtering costs, and increased pumping costs [2].

\subsection{Chemical Transformation Waste Streams}

To produce phosphoric acid, phosphate rock is chemically digested using sulfuric acid leading to the production of phosphgypsum. For each ton of phosphoric acid, five tons of phosphogypsum are produced. This category of waste is heavily studied in the literature and many reviews have been published [25,26]. In 2015, the world production of phosphoric acid was around 83 million tons [27]. Consequently, around 415 million tons of phosphogypsum was produced in 2015 alone.

As it is the case for the other waste streams, the properties of phosphogypsum are widely variable and depend on the nature of the phosphate rock, the chemical process, the disposal method, and many other parameters [28]. Phosphogypsum is mainly composed of gypsum, insoluble apatite, residual acids $\left(\mathrm{H}_{3} \mathrm{PO}_{4}, \mathrm{H}_{2} \mathrm{SO}_{4}\right.$, and $\left.\mathrm{HF}\right)$ and trace elements (F, REE, As, Cd, Cr, Pb, etc.). Many studies have been conducted to characterize phosphogypsum and its properties $[29,30]$. The environmental protection agency of the US (USEPA) has classified phosphogypsum as a "technologically enhanced naturally occurring radioactive material" (TENORM). It is called so because the most of naturally-occurring radionuclides (mainly uranium, thorium and radium) in phosphate rock remain in this byproduct. As a result of the concentration of radionuclides, phosphogypsum is considered more radioactive than the original phosphate rock.

\section{Environmental Impacts and Management Methods \\ 4.1. Environmental Impacts}

As in any extractive industry, enormous volumes of solid waste materials are produced during phosphate mining that have no current economic value and may present various potential impacts on environmental ecosystems. Large areas of land (many thousands of 
hectares) are commonly affected when surface mining is undertaken, including disturbance of land surface, removal of topsoil, excavation of ore and overburden, and construction of overburden dumps or solar evaporation ponds [12,31]. Two examples are highlighted in Figures 5 and 6. Figure 5 highlights the evolution of the environmental footprint related to phosphate extraction in an arid region in Morocco during the period between 1984 and 2020. In this case, two main problems have been encountered: occupation of large areas and dust generation. In Florida (Figure 6), in addition to occupation of large areas, many problems related to mine water drainage were reported [32,33]. The same problem was also observed in China where high ammonia nitrogen $\left(\mathrm{NH}_{4}{ }^{+}\right)$, nitrate $\left(\mathrm{NO}_{3}{ }^{-}\right)$, fluoride $\left(\mathrm{F}^{-}\right)$, and total nitrogen were detected in the outfalls of phosphate mining regions [34].

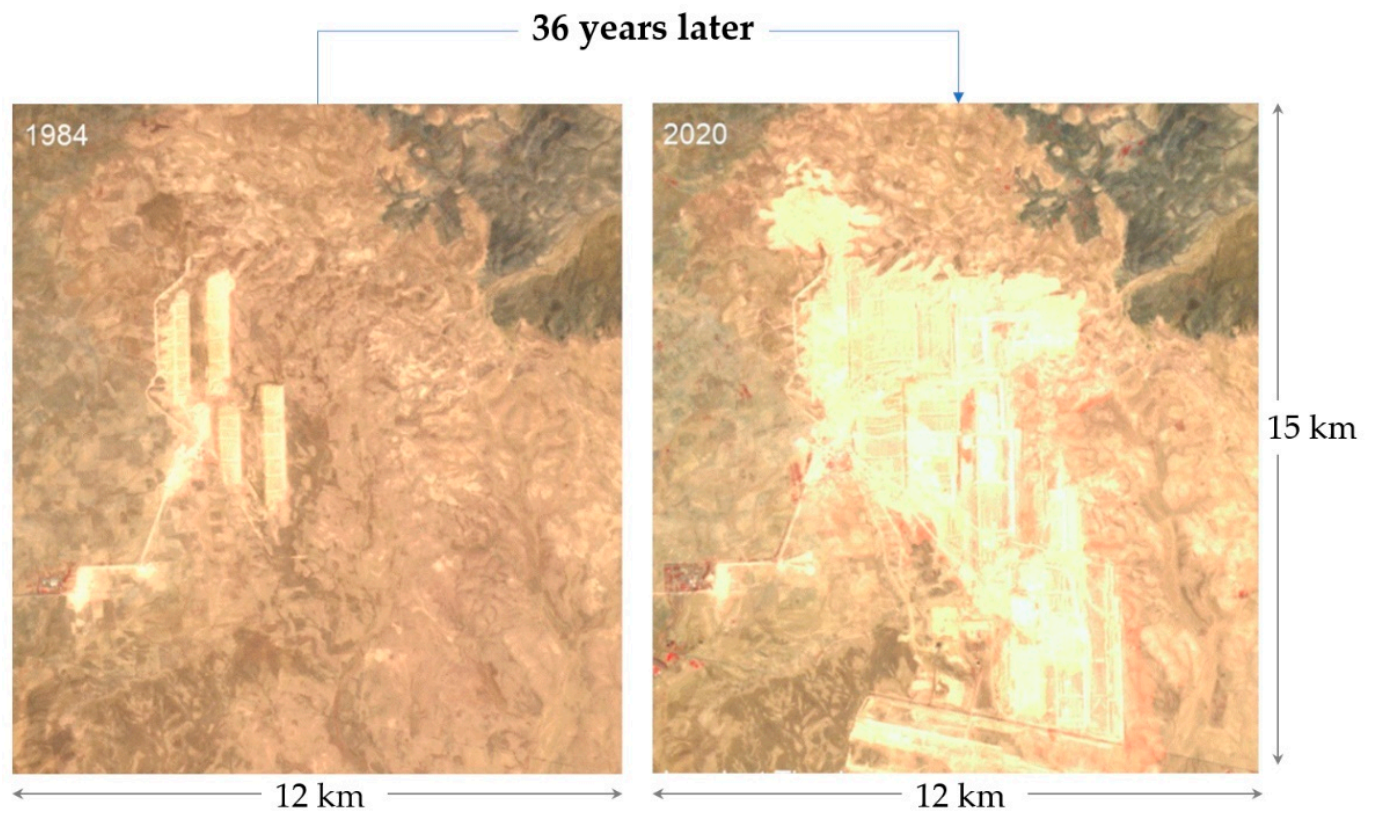

Figure 5. Satellite views of waste rock dumps evolution in the Gantour region in Morocco (1984 and 2020).

The topsoil and overburden are commonly placed in the proximity of the extraction sites in dumps designed for future rehabilitation and revegetation. However, the removal of topsoil and surface vegetation may affect not only the hydrological cycle and biodiversity of the area but may also lessen the arable lands used for agricultural purposes. It was demonstrated that the waste rock and sludge produced by the phosphate industry do not contaminate the quality of water (groundwater, nearby surface water, etc.) due to the presence of alkaline carbonate minerals and absence of sulfidic ones [35-37]. The effects of these wastes are mostly localized and confined to the mine site. It was reported in Florida that more than 73,000 ha of land were mined for phosphate between 1975 and 2005 [15]. From the large area that was mined, only $64 \%$ was completely reclaimed. It was estimated that a minimum of 100 years would be required to achieve a full restoration of mines in Florida (USA) if ecologically engineered practices are followed, or more than 500 years for natural attenuation [38].

During beneficiation, wastes such as oversized waste rock from screening, coarse flotation tailings, and clays fines are produced. These wastes are commonly associated with chemical reagents used during washing processes, which may present an environmental risk to surface water and groundwater if not properly managed. The volume and nature of the waste produced depend mainly on the characteristics and the constituents of the ore, the efficiency of the treatment process, the nature of the chemical reagents, and the presence of contaminants in the treated ore. Currently, the flotation tailings and sludges are mixed and disposed in specifically engineered dams and ponds. The accumulation of 
these phosphate waste products is of great concern due to their complex storage issues and potential dam failures [39-41].

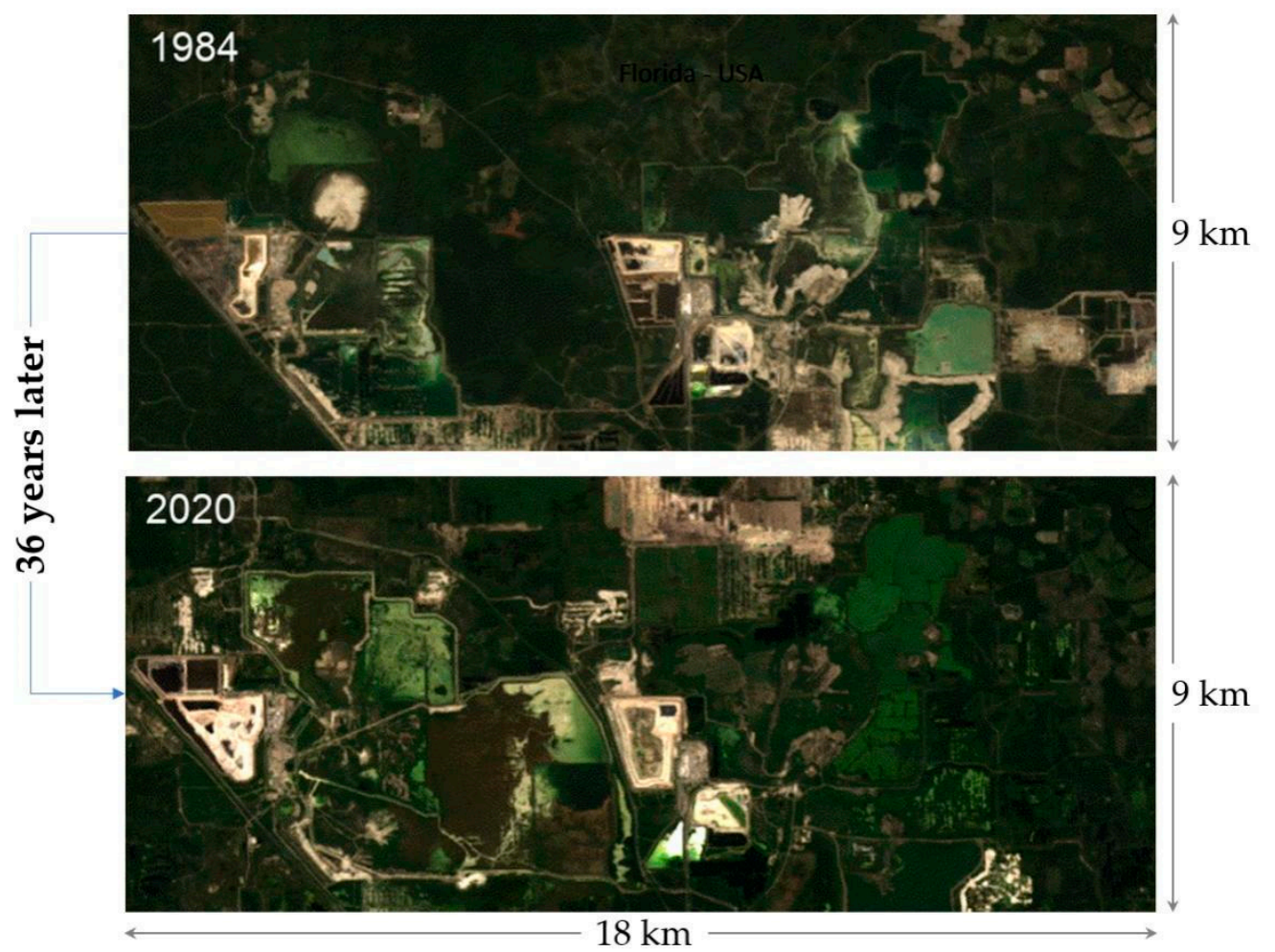

Figure 6. Satellite views of waste rock dumps and tailings ponds evolution in Florida, USA (1984 and 2020).

In such a case, due to its composition, phosphogypsum has been placed in stacks in many countries covering hundreds of hectares and reaching dozen meters of height (Figure 7). Risks of stacks failures and contaminated water infiltration are possible when safe and secure monitoring is absent. In some coastal regions, it may be discharged underwater. Due to its composition in terms of radionuclides and heavy metals [42,43], phosphogypsum could present many environmental impacts on soils and waters [44]: leaching of heavy metals due to weathering processes, chemical and radioactive contamination of surface and underground waters. Dissolved elements may be transferred to waters and finally to living beings $[45,46]$.

\subsection{Management Methods}

The main challenge for the mining industry in general is the management of the large volumes of mine wastes produced throughout the entire life cycle of the mine. These wastes may present potential environmental impacts if not properly managed and disposed of in a safe, stable, and environmentally sound manner $[47,48]$. The objective of the mining industry is to limit the environmental impacts as much as possible over the short, medium, and long terms. For this reason, various waste management methods have been developed over the recent decades [49]. Researchers have also made a good progress regarding the replacement of classic and conventional methods of storage with more sustainable and integrated management techniques [50].

Currently, the waste management methods mainly employed consist of dumping the overburden in spoil piles or for the construction of containment dykes, the construction of ponds or dams for the storage of the beneficiation tailings, the discharge of wastes to oceans and rivers (sometimes with release controls), or the backfilling of these wastes into the mined-out openings [51]. The construction of engineered containment infrastructure allows the confinement of the various environmental impacts to a limited and controlled area. In 
terms of phosphogypsum, the USEPA has required its placement in stacks. However, it is not the case everywhere, phosphogypsum is sometimes sent to rivers, seas and oceans [29].

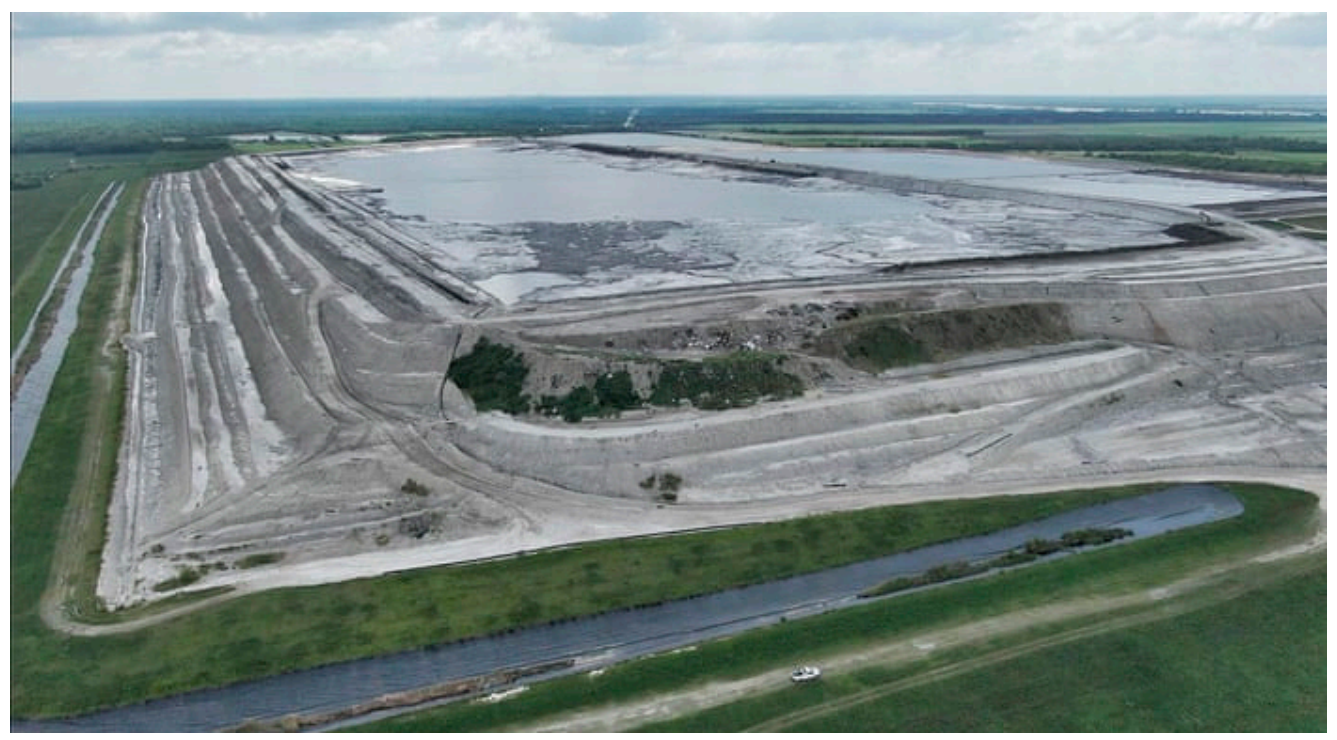

Figure 7. Phosphogypsum stacks in Florida (The Mosaic pile. Photograph: Phin Percy).

When the management methods are not controlled in a sufficiently safe and secure way, this could lead to dramatic and serious social, environmental, and economic impacts [52]. The installation of control and monitoring systems is of high importance to detect the first signs of failure and minimize the possibility of accidental release.

\section{Circularity Opportunities}

As mentioned previously, the mining industry is following linear thinking in terms of waste management, leading to various risks to human health and the environment. However, those wastes, or what we think of as wastes, can be transformed into useable products via reuse, recycling, and recovery. This is very important to decrease the demand for new nonrenewable resource quarries and the associated environmental impacts, and more importantly to generate economic profits [53-56]. The need to explore alternative and sustainable resources is becoming an urgent task for decision makers and stakeholders. Phosphate waste streams could present a potential alternative to recover lost phosphate minerals and other strategic raw materials, thus responding to the increasing need for construction and building materials and generating profit. However, significant efforts are still required to implement the objectives of circularity in the mining sector. Enormous circularity opportunities have been identified in the literature, but there is still a long way to go in this area. This section aims to highlight the recent advances and opportunities related to the reuse and recovery of phosphate wastes (one of the largest waste streams) by way of a thorough literature review.

\subsection{Waste Minimization}

A rethinking of novel and sustainable management of mine wastes is necessary to achieve the overall objectives of sustainable development goals. As stated in Figure 8, the preferred options are the prevention of mining wastes or their minimization from the source. Reuse, recycling, and resource recovery are also favored to transform these materials "without any value" to high value products [47]. The last desirable option is to landfill wastes in a safe and sustainable way. 


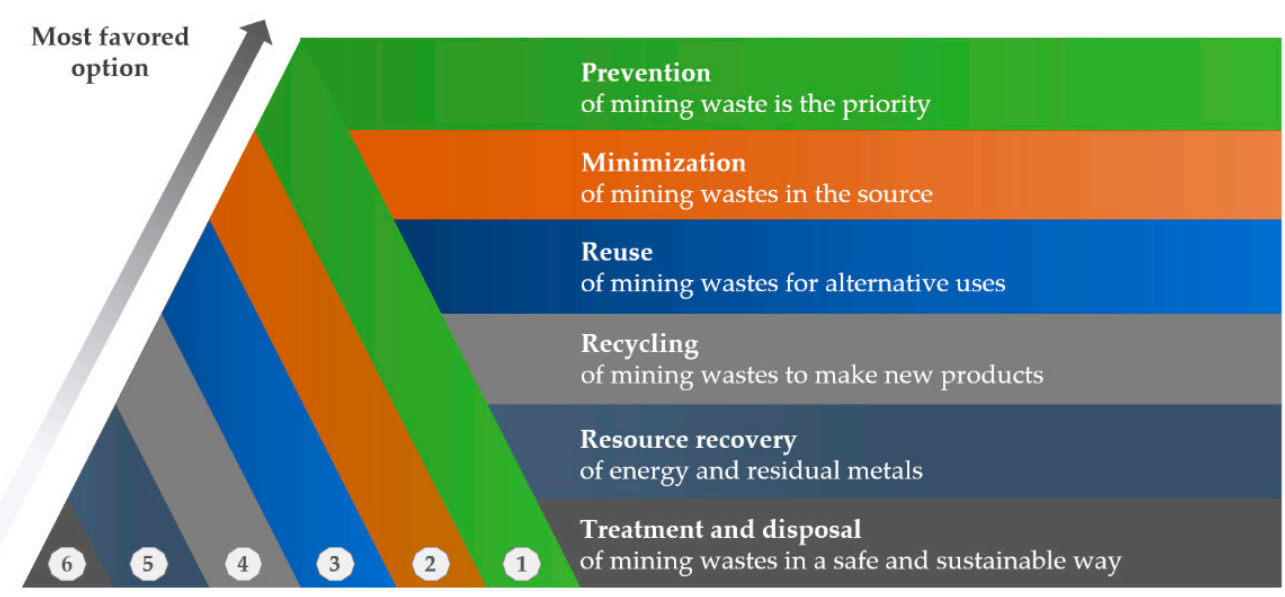

Figure 8. Waste management hierarchy from prevention to treatment and disposal.

\subsection{Phosphate Recovery}

The recovery of phosphate during mining and beneficiation has never been efficient using traditional methods. Mining companies were always interested in readily extractible and high-grade phosphate ores. Lower grade and complex ores are neither extracted nor treated due to the presence of impurities (e.g., dolomite, cadmium, etc.), insufficient thickness, location under hard-calcareous and flintstone layers, etc. [57]. Therefore, some unwanted layers are just left in the ground or mixed with waste rock and sent for disposal. In other words, significant losses of phosphate may occur when associated with unwanted minerals such as dolomite and clays. Other losses may occur during processing, leading to the generation of waste rock with relatively high $\mathrm{P}_{2} \mathrm{O}_{5}$ content [58]. Currently, traditional screening methods are still used in the first extraction steps. Many losses of $\mathrm{P}_{2} \mathrm{O}_{5}$ may also occur when the vibratory screens are underdimensioned or when the phosphatic ore presents a high humidity rate. Very fine phosphate particles could be lost during the removal of clays by desliming or flotation with limestone [59]. The loss of phosphate in the various waste streams results not only in economic losses but also, and more importantly, the need to extract more phosphate ores.

No detailed studies have been conducted in Morocco to estimate either the mass fraction of $\mathrm{P}_{2} \mathrm{O}_{5}$ in the different waste streams or the volume of lost phosphate. In the USA, it was estimated that the mass fraction of $\mathrm{P}_{2} \mathrm{O}_{5}$ in bulk sediment varies from approximately 4 to $21 \mathrm{wt} \%$ with an average of $14 \mathrm{wt} \%$ [15]. It was also reported that one third of the phosphate in the original ore matrix lies in the clay tailings [60]. The majority of this lost phosphate is concentrated in the very fine clay fraction $(<2 \mu \mathrm{m})$. The current beneficiation technologies, mainly gravity separation techniques and flotation, are very limited in these grain size distributions. More efficient technologies are needed to recover phosphate from clays.

Due to the strategic importance of phosphorus and its growing scarcity in many countries, research efforts have increased recently to recover phosphorus from different mine waste streams. Those studies are mainly concerned with the development of novel treatment solutions to recover the lost phosphate in tailings and low-grade ores. Froth flotation was the most common method to deal with low grade ores due to the higher selectivity and recovery rates [61]. Direct froth flotation was used by Alsafasfeh and Alagha [62] to upgrade the $\mathrm{P}_{2} \mathrm{O}_{5}$ content in tailings $\left(21.57 \% \mathrm{P}_{2} \mathrm{O}_{5}\right)$ from a phosphorus beneficiation plant. Results showed that a recovery greater than $73 \%$ and a concentrate upgrade to $28.4 \%$ $\mathrm{P}_{2} \mathrm{O}_{5}$ can be achieved using sodium silicate (dispersant) and sodium oleate (collector). Oliveira et al. [63] evaluated the recovery of apatite from phosphate flotation tailings from a Brazilian fertilizer manufacturer using column flotation. The authors succeeded in obtaining a phosphate concentrate of $29.4 \% \mathrm{P}_{2} \mathrm{O}_{5}$ and a recovery of $46.2 \%$ using a mixture of a synthetic reagent and rice bran oil soap. In another study in Brazil, fine (38-13 $\mu \mathrm{m})$ 
and ultrafine $(<13 \mu \mathrm{m})$ phosphate particles were successfully recovered from clay tailings using column flotation coupled with high intensity conditioning [64].

\subsection{Recovery of Other Critical Elements}

Mining companies tend to focus their recovery on the metal/mineral of interest. The recovery of other elements is generally not considered in the initial design plans. Significant value is lost in the generated waste streams. Due to the growing prices of metals, the depletion of resources, and the monopolization of markets by a few countries, research efforts to find alternative sources of critical raw materials have gained much interest.

Phosphate rock is known to contain traces of critical raw materials such as rare earth elements (REE) and uranium (U) [65,66]. Many studies have been conducted on the recovery of REE from phosphate rock, phosphogypsum, phosphoric acid slurry, and phosphoric acid [67-69]. However, limited research has been conducted on the recovery of REE from waste rock, tailings, and sludge. Phosphate flotation tailings from central Florida (assaying 2.6\% $\mathrm{P}_{2} \mathrm{O}_{5}$ and $198.2 \mu \mathrm{g} / \mathrm{g}$ REEs) were upgraded to recover REEs using gravity separation and flotation processing followed by leaching and precipitation processes [70]. The authors demonstrated that precipitates assaying $0.926 \%$ REEs and $0.716 \%$ REEs can be achieved after the leaching of flotation and table concentrates, respectively. However, these mass fractions are not high enough to stand as a REE feed. The authors suggested combining this concentrate with REEs concentrated from other phosphate waste streams, such as phosphogypsum, waste clay, or phosphoric acid sludge. In Sweden, for example, the LKAB mining company has successfully developed a pilot plant to recover apatite, REE, fluorine, and gypsum by reprocessing iron-ore tailings. This solution will help the company not only to manage its environmental footprint and costs, but also to secure an additional revenue stream [71,72]. Phosphate sludge was also characterized in Tunisia to evaluate the REE content [73]. Results highlighted the presence of non-negligible amounts of REE (around $480 \mathrm{mg} / \mathrm{kg}$ ) in sludge, particularly concentrated in the coarse fraction.

\subsection{Application of Wastes as Alternative Raw Materials}

The transformation of mine waste from a risk into an opportunity has gained greater importance in the recent decade. Terms like "valorization", circularity", "reuse", and "recycling" were used by many authors to present their novel and sustainable management strategies for mine wastes. Few mining companies have even started to discuss "circularity" and "closed-loop systems" in their waste management strategies. However, this field is not sufficiently developed to help individual mining companies contribute to the circular economy. Each mine site is unique, as are the characteristics of the wastes. A large proportion of these wastes are inert and do not present any drainage risk. In phosphate mining, the majority of mining wastes are in the form of clays, sand, and gravel.

The need for clay, sand, and gravel in the construction sector is very high; these materials constitute the largest resource consumption in the world. The consumption of sand, gravel, and crushed rock is expected to reach 55 gigatons by the year 2060, compared to 30 gigatons/year in 2018 [74]. To respond to this need of materials, there is pressure to open new quarries and develop new infrastructure. Also, the use of these extracted materials causes to the release of greenhouse gas (GHGs) emissions and consequently climate change. Huge volumes of waste rock and tailings (hundred million tons per year) are generated by mining companies; diverting these wastes for use in construction is far more sustainable and ecofriendly than extracting new materials.

Mining companies have long been looking inside the box and focusing on their products and local waste management methods. As a result, mining companies are losing many opportunities by ignoring solutions outside their own circles. Waste valorization is not only a pollution control solution and a cost-effective management method but also a business opportunity.

The characterization of phosphate waste rock for the purpose of valorization has been investigated by few authors. An overview of the main opportunities and challenges 
of phosphate waste rock and sludge valorization from Moroccan phosphate mines was presented in [75]. Applications to the construction sector, civil engineering field, ceramic manufacturing, and acid mine drainage pollution control were suggested. The characterization of the main components of phosphate interlayer materials in Morocco was evaluated in [76]. Results showed that significant volumes of industrial minerals are present in these materials in the form of carbonaceous minerals (calcite and dolomite), siliceous minerals (quartz, tridymite, and cristobalite), aluminosilicates (clays), and phosphates (francolite). Those abandoned minerals could represent a promising resource to feed many nonphosphate sectors such as cement manufacturing, road infrastructure, pyrometallurgical industries, agriculture, green energy-based technologies, etc. The potential use of these materials is still underexplored.

\subsection{Civil Engineering Applications}

As stated in [75], phosphate waste rock presents promising geotechnical properties and could be an excellent alternative secondary raw material to conventional borrow pits. Later, Amrani et al. [77] investigated the use of phosphate waste rock as material for road construction. The authors justified their approach based on the fact that phosphate waste rock is similar to conventional aggregate, which has not been subjected to any transformation other than mechanical fragmentation. The characterization and pilot test results showed that the sampled phosphate waste rock met the required geotechnical properties for materials to be used in embankment applications. Furthermore, the investigation of the effect of dry compaction on the stability behavior of phosphate waste rock as embankment material was assessed [78]. Dry compaction is a growing solution in arid regions as it minimizes water use. The results of the study confirmed the ability of phosphate waste rock to be used as embankment material at dry moisture content under total overburden stress below $200 \mathrm{kPa}$. Another application of phosphate waste rock, phosphate sludge, and phosphogypsum as asphalt binder additives was evaluated [79]. The results showed that the phosphogypsum-based asphalt binder performed better than the phosphate sludge-based binder in terms of the mechanical behavior and rutting resistance. It was also demonstrated in another study that phosphogypsum can be successfully used as an embankment and pavement material when mixed with a calcareous material and clayey soil [80]. Due to its acidity, phosphogypsum stabilized with alkaline materials and low-cost cementitious materials is an innovative and sustainable solution to help open new horizons for phosphogypsum reuse.

\subsection{Construction and Building Materials}

As stated in the preview report released by the Organisation for Economic Cooperation and Development [74], resource consumption will more than double by 2060, leading to significant environmental consequences. Construction and building materials (such as sand, gravel, limestone, and crushed rock) is now the largest resource-consuming sector, and is expected to grow significantly in the future (more than half of total materials). At the same time, more wastes with similar properties to those used in the construction sector will be produced by the mining sector all over the world. The creation of synergy between both sectors is a must and should be developed as soon as possible due to the growing demand for these materials, particularly in developing countries. The use of materials in a sustainable and ecofriendly manner is a major challenge for both the mining and construction sectors. Many environmental and economic opportunities exist for uptake by companies in these sectors.

Researchers demonstrated that waste rock and tailings derived from the mining sector are good materials for the construction and building sector. The use of raw destoning waste rock as alternative aggregate in concrete manufacturing was assessed by El Machi et al. [81]. It was confirmed that destoning waste rock does not meet the requested geotechnical properties for concrete standards in its current form. This was explained by the presence of a substantial volume of crumbly limestones and marls in the mix. The authors stated 
that concrete samples with higher mechanical performance can be achieved when the percentage of flintstone aggregates in the mix is increased. After manual sorting, the authors succeeded in completely replacing the conventional aggregates with flintstone aggregates, thus developing a concrete sample with higher mechanical performance [82]. This solution requires improvement, as the materials remaining after sorting (limestones and marls) are not used. Limestones are mainly composed of dolomite and calcite minerals, while marls are composed of clayey minerals (montmorillonite and palygorskite), quartz, and limestones.

The use of waste rock as an alternative raw material in the cement industry has not yet been developed in the literature. This is surprising, given that a significant proportion of waste rock is composed of calcite and clayey minerals, which are the main raw materials for clinker production. Researchers were often focused on the use of tailings rather than waste rock. The use of phosphate tailings in Portland cement as filler was investigated by Zheng et al. [83]. The authors concluded that the presence of phosphorus and dolomite significantly affect the setting time, strength, and drying shrinkage of cement pastes. A small proportion of phosphorus tends to dissolve during the early stage of hydration and leads to setting delays due to precipitation. Bahhou et al. [84] investigated the use of marls as supplementary cementitious materials. It was demonstrated that marls can be activated at calcination temperatures around $800{ }^{\circ} \mathrm{C}$ and replace more than $20 \%$ of clinker in cement formulations. The incorporation of calcined marls in cement manufacturing will lead not only to the reduction of GHG emissions but also the costs of production. However, some challenges related to the chemical heterogeneity of marl-rich wastes, their pozzolanic activity after activation, compatibility with conventional plasticizers, and the durability of calcined marl-based concrete still need to be overcome [85].

The use of marl-rich wastes as secondary raw materials for the manufacturing of ceramic materials [86], fired bricks [87], and lightweight aggregates [88] was also evaluated. All these studies demonstrated that marl wastes can be efficiently used to manufacture good quality ceramic products in terms of mechanical performance, water absorption, and porosity.

In terms of phosphate sludge or phosphate tailings, many reuse studies have been conducted. Negm and Abouzeid [89] demonstrated that phosphate washing plant tailings could be upgraded to produce a high-grade phosphate concentrate (more than $30 \% \mathrm{P}_{2} \mathrm{O}_{5}$ at over $90 \%$ recovery), aggregates for concrete mixes, brick manufacturing ( $90 \%$ phosphate slimes and $10 \%$ shale), and pottery (from ultrafine fraction $<40 \mu \mathrm{m}$ ). Phosphate processing sludge as a raw material for fired brick making was also evaluated [73]. As already demonstrated in other papers [59], this study highlights the nonplastic properties of phosphate sludge due to the low clay content. The addition of high-plasticity materials (e.g., clays, chemical additives) is always required to improve the final plasticity of the mix. Furthermore, ceramisite products were successfully synthesized using phosphate tailings, soft interlayers, and black shales [90]. The ceramisite materials are known for their good corrosion and freeze resistance, which allows many applications as building, refractory, and thermal insulation materials.

Phosphate wastes could also be used to produce ecofriendly and low-carbon binders such as geopolymers and alkali-activated materials [91]. Wastes are generally used in their natural state, sorted and separated from other wastes, calcined at moderate temperatures for activation purposes or mixed with other additives (metakaolin, fly ash, slag). Basic and activation solutions are also used in the mix formulations. The use of wastes could be an interesting alternative to substitute limited and unavailable resources such as metakaolin and fly ashes. Yellow clays from phosphate intercalation layers (unexploited resource) were calcined at $800{ }^{\circ} \mathrm{C}$ to synthetize alkali-activated materials [92]. A compressive strength of $25 \mathrm{MPa}$ was obtained with sodium silicate/sodium hydroxide ratio of 0.5 . Red clays from the same extraction region were also investigated as a filler in alkali-activated materials [93]. Results showed that a compressive strength of 39MPa can be achieved. Moukannaa et al. [94] succeeded to prepare geopolymers with compressive strength of 
$62 \mathrm{MPa}$ using noncalcined phosphate sludge, fly ash and metakaolin. To activate phosphate sludge and rich higher substitution rates, Dabbebi et al. [95] demonstrated that the calcination do not allow to enhance the workability of phosphate washing waste-based geopolymers. An average compressive strength of 10MPa was achieved for mortars.

Phosphogypsum has also been used in many applications in the construction sector as an alternative raw material for cement, plaster [96,97] and brick making [98]. It was used as a setting retarder in the cement formulation [99] and a secondary raw material in gypsum plaster making $[100,101]$. When mixed with other industrial byproducts such as fly ash, phosphogypsum can be used to develop novel binders [102]. Real applications of phosphogypsum have strongly been limited due to the presence of many undesired chemical elements and low acidity. It was reported that residual fluorides and phosphate increase the setting time and decrease the mechanical strength development of cement paste [103]. The presence of naturally occurring radionuclides is also a big issue as radioactivity in building could directly affect human's health and wellbeing. Accordingly, many processing methods have been developed to remove the undesired pollutants: washing, wet sieving, alkaline neutralization, and addition of extractant solutions $[29,104]$. Those methods produce a harmless material in the building sector. However, many research activities are still ongoing about the radioactivity of phosphogypsum and its use as a building material.

\section{Challenges Facing Circularity in the Phosphate Industry}

It is worth mentioning that the circular economy in the mining sector is still not very clear and further effort is needed to achieve this transformation [54,105]. Circular economy implementation is limited due to five different categories of challenges (Table 2). Those challenges are interconnected and cannot be resolved by one company alone. Many public and private stakeholders and decision-makers need to work together alongside academic researchers to develop concrete solutions for circularity.

One of the major challenges is the high heterogeneity of waste materials from one site to another, combined with the presence of impurities and unwanted materials [5]. The variation of these materials will significantly affect long-term circularity scenarios. A detailed understanding of the variability in the chemical (major, minor, and trace elements), mineralogical (minerals content and their distribution), and geotechnical (hardness, particle size, density, water content, etc.) properties of the wastes is essential. The development of viable technologies to deal with this high heterogeneity is required.

Knowledge gaps in terms of the properties of the wastes, including the metal content, and radioactivity, are also important challenges. The main challenge is to prove that these materials are stable and inert and will not present any risk to human health and the environment. The environmental and toxicological behavior of novel mine wastebased products is not sufficiently understood. Risks related to the leaching of metals and metalloids and to the exploitation of materials from old dumps are not predictable. Most of the solutions based on a thermal treatment of solid wastes (ceramics, cements, etc.) do not take into account the potential release of gases. Some gaseous pollutants could be generated $\left(\mathrm{SO}_{\mathrm{x}}, \mathrm{CO}_{\mathrm{x}}, \mathrm{NO}_{\mathrm{x}}\right.$, etc.). Efforts should be made to better understand the interactions of these novel materials with the local ecosystem and their long-term behavior.

From a regulation policy perspective, mine waste reuse outside the mine site is limited due to the absence of legislation and permitting for the reuse and recycling of these materials. For example, reuse of mine wastes in the construction of roads and parking lots is an authorized practice in China [106,107]. Suitable environmental impacts and life cycle assessment studies should be included in the first circular models. Incentives to diminish the environmental impacts of these wastes through reuse are still not sufficiently developed to help mining companies move towards a circular economy approach. 
Table 2. Synthesis of the main challenges facing circularity in phosphate industry.

\begin{tabular}{|c|c|c|}
\hline Category & Challenges & References \\
\hline Technology & $\begin{array}{l}\text { Heterogeneity of secondary materials } \\
\text { Removal of impurities in waste materials } \\
\text { Waste rock sorting } \\
\text { Waste processing efficiency } \\
\text { Difficult access to waste materials }\end{array}$ & {$[5,54,105,108,109]$} \\
\hline Environment & $\begin{array}{l}\text { Leaching of heavy metals and metalloids } \\
\text { Emissions of gaseous pollutants (thermal } \\
\text { treatment applications) } \\
\text { Risks associated with opening old heaps }\end{array}$ & {$[5,53,108]$} \\
\hline Regulation & $\begin{array}{l}\text { Absence of legislation regarding the sustainable use } \\
\text { of mine wastes in other sectors } \\
\text { Absence of legal obligations on the recovery of P } \\
\text { from the different waste streams } \\
\text { Legislation on environmental requirements } \\
\text { Legislation on contaminated land rehabilitation } \\
\text { Environmental permits }\end{array}$ & {$[5,105,108,109]$} \\
\hline Economy & $\begin{array}{l}\text { Lower price of virgin materials } \\
\text { Presence of minerals of interest in wastes: potential } \\
\text { future reserves } \\
\text { Low markets } \\
\text { Investment costs } \\
\text { High costs associated with building new } \\
\text { process factories } \\
\text { Cost of logistics }\end{array}$ & {$[5,53,54,105,108]$} \\
\hline Social & $\begin{array}{l}\text { Social acceptance } \\
\text { Societal awareness }\end{array}$ & {$[5,53,108]$} \\
\hline Knowledge gaps & $\begin{array}{l}\text { Mineralogy, metal concentrations, and radioactivity } \\
\text { of wastes } \\
\text { Long term behavior of novel waste-based materials } \\
\text { Market price }\end{array}$ & {$[5,105,108]$} \\
\hline
\end{tabular}

From an economic point of view, it was stated by most researchers that the main challenge could be related to the low price of virgin raw materials and their proximity to the market. Mine wastes are generally located in remote areas and the costs for their sorting, transport, and logistics are in some cases higher than those for virgin raw materials, which limits their reuse. Furthermore, the investment costs for waste processing and sorting are still high. There is a need for more efficient technologies for the large-scale production of construction materials to decrease the treatment costs and maximize the associated benefits. From a consumer perspective, awareness regarding the safe use of mine waste-based products is insufficient; further efforts are still needed from the scientific community, nongovernmental organization (NGOs), and institutions to promote the social acceptance of those novel products.

\section{Recommendations and Conclusions}

Waste management is one of the main challenging tasks for the phosphate mining industry, not only due to the huge volumes of waste, but also due to the potential impacts on the environment and the well-being of local populations. The transformation of these wastes from materials with no value (source of problems) into useful and profitable secondary resources is a sustainable and ecofriendly solution. However, many complex parameters, including the absence of long-term strategies and viable technologies, are limiting this transition. To tackle these complex issues, a novel rethinking of the traditional approach to phosphate mining and waste management is needed. The achievement of these objectives requires the development of a synergistic consortium of interconnecting 
companies and universities that form our infrastructure and economy. Instead of being trapped in the frustrations of the present, it is time to open new perspectives and horizons for new thinking to innovatively redesign the future of phosphate mining.

When it comes to circularity, the mining companies are always limited by the huge volume (hundred million tons per year) of wastes they have produced and continue to generate. From their point of view, there is no company who is capable of consuming all the wastes. From our point of view as researchers, numerous opportunities exist and should be investigated. It is time to change our mindset and start looking at waste differently. Many construction and building materials companies could be interested in the materials they are producing.

It is inaccurate to consider all phosphate waste streams to be waste materials. A material can be considered as a waste only when it has been proven that the material is no longer useful. Otherwise, what we currently label as waste should instead be considered a byproduct. This definition should be carefully considered due to the potential depletion of natural resources and the continuous demands of society.

The minimization and recycling/reuse of wastes could provide a valuable opportunity to develop a sustainable and resource-efficient economy moving forward. Those wastes are generally inert and stable and should be considered as conventional resources to be consumed in other sectors. Two main approaches should be considered. The first approach is to rethink current production processes to minimize the production of waste materials as much as possible. The minimization of waste at the source is the most sustainable solution to consider. The second approach is to deal with the materials that are already stored in many dumps, waste rock piles, and tailings ponds.

Characterization of the different waste streams is a crucial step towards valorization. Identification of the properties of the wastes at the early stage of exploration will help to select the most important materials for consumption by the market. Once identified, the viable materials should be separated and stored for a potential future use. A rethinking of conventional mining activities is required to move towards a selective extraction of the ore and interlayers. Ore sorting, which is currently used by many mining industries around the world, is an interesting technology to achieve a good selectivity of materials. This nondestructive technology helps to upgrade the quality of low-grade ores by removing the unwanted minerals. It covers a large particle size range from few to dozens of millimeters. For example, this technology is currently used in Saudi Arabia to upgrade the low-grade phosphate ores by removing flintstones (more than $70 \%$ of the run-of-mine material) [110]. By doing so, the mine generates two streams: a phosphate rock-rich ore and a silicarich waste rock. The silica-rich waste rock is currently considered to be waste, although flintstones could be used in many applications. A rethinking of the use of this technology could help not only to upgrade the phosphate rock but also to reuse the rejected materials.

From a regulation perspective, it is time to introduce novel environmental taxes and incentives to promote sustainable resource management and minimize environmental impacts. It is important to consider the environmental impacts derived from various sectors, not only from the mining sector. For instance, the impacts derived from the extraction of sand, gravel, and aggregates and their use in the construction and building sector must also be considered. With the presence of taxes, the polluter will have to pay for their environmental footprint. With incentives, a synergy between the mining and construction sectors will be anticipated. The support of policy makers and R\&D investment by mining companies are required to reach sustainable mining and to improve social awareness.

Author Contributions: Conceptualization, Y.T.; validation, M.B., R.H. and A.E.; investigation, Y.T., M.B., R.H. and A.E.; writing—original draft preparation, Y.T.; writing—review and editing, Y.T., M.B., R.H. and A.E.; supervision, M.B. and R.H. All authors have read and agreed to the published version of the manuscript.

Funding: This research received no external funding.

Data Availability Statement: The study did not report any data. 
Conflicts of Interest: The authors declare no conflict of interest.

\section{References}

1. USGS. U.S. Geological Survey; Mineral Resources Program (MRP): Washington, DC, USA, 2020.

2. Kawatra, S.K.; Carlson, J. Beneficiation of Phosphate Ore; Society for Mining, Metallurgy, and Exploration: Englewood, CO, USA, 2013.

3. Taha, Y.; Benzaazoua, M. Editorial for Special Issue: “Recent Trends in Phosphate Mining, Beneficiation and Related Waste Management". Minerals 2019, 9, 755. [CrossRef]

4. Esposito, M.; Tse, T.; Soufani, K. Is the circular economy a new fast-expanding market? Thunderbird Int. Bus. Rev. 2017, 59, 9-14 [CrossRef]

5. Kinnunen, P. Towards Circular Economy in the Mining Industry: Implications of Institutions on the Drivers and Barriers for Tailings Valorization. Master's Thesis, Tampere University, Tampere, Finland, 2019.

6. H2020-WASTE-2015-two-stage. Waste: A resource to recycle, reuse and recover raw materials. In Call for Proposals, Specific Programme: EU.3.5.4.; European Commission: Brussels, Belgium, 2013.

7. ERA-MIN. Raw materials for the sustainable development and the circular economy. In EU Co-Funded ERA-MIN Joint Call 2021; European Commission: Brussels, Belgium, 2021.

8. $\quad$ Berg, A.; Antikainen, R.; Hartikainen, E.; Kauppi, S.; Kautto, P.; Lazarevic, D.; Piesik, S.; Saikku, L. Circular Economy for Sustainable Development; Finnish Environment Institute: Helsinki, Finland, 2018.

9. De Sousa Jabbour, A.B.L.; Jabbour, C.J.C.; Godinho Filho, M.; Roubaud, D. Industry 4.0 and the circular economy: A proposed research agenda and original roadmap for sustainable operations. Ann. Oper. Res. 2018, 270, 273-286. [CrossRef]

10. Kalmykova, Y.; Sadagopan, M.; Rosado, L. Circular economy-From review of theories and practices to development of implementation tools. Resour. Conserv. Recycl. 2018, 135, 190-201. [CrossRef]

11. Mathews, J.A.; Tan, H.; Hu, M.-C. Moving to a circular economy in China: Transforming industrial parks into eco-industrial parks. Calif. Manag. Rev. 2018, 60, 157-181. [CrossRef]

12. IFIA. Environmental Aspects of Phosphate and Potash Mining; International Fertilizer Association: Paris, France; UNEP: Paris, France, 2001.

13. Tagieddin, S.A. Applicability of blast casting technique in strip-mining phosphate rock. Eng. Geol. 1992, 33, 127-139. [CrossRef]

14. Beavers, C.; Ellis, R.; Hanlon, C.; MacDonald, G. An Overview of Phosphate Mining and Reclamation in Florida. Master's Thesis, University of Florida, Gainesville, FL, USA, 2013.

15. Krekeler, M.P.; Morton, J.; Lepp, J.; Tselepis, C.M.; Samsonov, M.; Kearns, L.E. Mineralogical and geochemical investigation of clay-rich mine tailings from a closed phosphate mine, Bartow Florida, USA. Environ. Geol. 2008, 55, 123-147. [CrossRef]

16. Singh, S.; Ma, L.; Hendry, M. Characterization of aqueous lead removal by phosphatic clay: Equilibrium and kinetic studies. J. Hazard. Mater. 2006, 136, 654-662. [CrossRef]

17. Moudgil, B.; Mathur, S.; Behl, S. Flocculation behavior of dolomite with poly (ethylene oxide). Min. Metall. Explor. 1995, 12, 219-224. [CrossRef]

18. Guan, C. Theoretical background of the Crago phosphate flotation process. Min. Metall. Explor. 2009, 26, 55-64. [CrossRef]

19. Shang, J.; Lo, K. Electrokinetic dewatering of a phosphate clay. J. Hazard. Mater. 1997, 55, 117-133. [CrossRef]

20. El-Shall, H.; Zhang, P.; Snow, R. Comparative analysis of dolomite/francolite flotation techniques. Min. Metall. Explor. 1996, 13, 135-140. [CrossRef]

21. Moudgil, B.; Chanchani, R. Selective flotation of dolomite from francolite using two-stage conditioning. Min. Metall. Explor. 1985 2, 19-25. [CrossRef]

22. Yang, B.; Zhu, Z.; Sun, H.; Yin, W.; Hong, J.; Cao, S.; Tang, Y.; Zhao, C.; Yao, J. Improving flotation separation of apatite from dolomite using PAMS as a novel eco-friendly depressant. Miner. Eng. 2020, 156, 106492. [CrossRef]

23. Wang, T.; Feng, B.; Guo, Y.; Zhang, W.; Rao, Y.; Zhong, C.; Zhang, L.; Cheng, C.; Wang, H.; Luo, X. The flotation separation behavior of apatite from calcite using carboxymethyl chitosan as depressant. Miner. Eng. 2020, 159, 106635. [CrossRef]

24. Dong, L.; Wei, Q.; Qin, W.; Jiao, F. Selective adsorption of sodium polyacrylate on calcite surface: Implications for flotation separation of apatite from calcite. Sep. Purif. Technol. 2020, 241, 116415. [CrossRef]

25. Saadaoui, E.; Ghazel, N.; Ben Romdhane, C.; Massoudi, N. Phosphogypsum: Potential uses and problems-A review. Int. J. Environ. Stud. 2017, 74, 558-567. [CrossRef]

26. Bandgar, G.S.; Kumthekar, M.B.; Landage, A.B. A review of effective utilization of waste phosphogypsum as a building material. Int. J. Eng. Res. 2016, 5, 277-280.

27. EPFA. Phosphoric Acid Statistics; European Phosphate Fertilizer Alliance, Alliance Européene des Engrais Phosphatés: Bruxelles, Belgium, 2015.

28. Arman, A.; Seals, R. A preliminary assessment of utilization alternatives for phosphogypsum. In Proceedings of the Third International Symposium on Phosphogypsum, Orlando, FL, USA, 4-6 December 1990; p. 83.

29. Tayibi, H.; Choura, M.; López, F.A.; Alguacil, F.J.; López-Delgado, A. Environmental impact and management of phosphogypsum. J. Environ. Manag. 2009, 90, 2377-2386. [CrossRef]

30. Chernysh, Y.; Yakhnenko, O.; Chubur, V.; Roubík, H. Phosphogypsum Recycling: A Review of Environmental Issues, Current Trends, and Prospects. Appl. Sci. 2021, 11, 1575. [CrossRef] 
31. Yang, Y.Y.; Wu, H.N.; Shen, S.L.; Horpibulsuk, S.; Xu, Y.S.; Zhou, Q.H. Environmental impacts caused by phosphate mining and ecological restoration: A case history in Kunming, China. Nat. Hazards 2014, 74, 755-770. [CrossRef]

32. Lamoreaux, P.E. Water development for phosphate mining in a karst setting in Florida-A complex environmental problem. Environ. Geol. Water Sci. 1989, 14, 117-153. [CrossRef]

33. Lewelling, B.; Wylie, R. Hydrology and Water Quality of Unmined and Reclaimed Basins in Phosphate-Mining Areas, West-Central Florida; US Geological Survey: Washington, DC, USA, 1993; Volume 93.

34. Wang, K.; Lin, Z.; Zhang, R. Impact of phosphate mining and separation of mined materials on the hydrology and water environment of the Huangbai River basin, China. Sci. Total Environ. 2016, 543, 347-356. [CrossRef] [PubMed]

35. Hakkou, R.; Benzaazoua, M.; Bussiere, B. Laboratory evaluation of the use of alkaline phosphate wastes for the control of acidic mine drainage. Mine Water Environ. 2009, 28, 206-218. [CrossRef]

36. Ouakibi, O.; Loqman, S.; Hakkou, R.; Benzaazoua, M. The potential use of phosphatic limestone wastes in the passive treatment of AMD: A laboratory study. Mine Water Environ. 2013, 32, 266-277. [CrossRef]

37. Bossé, B.; Bussière, B.; Hakkou, R.; Maqsoud, A.; Benzaazoua, M. Field experimental cells to assess hydrogeological behaviour of store-and-release covers made with phosphate mine waste. Can. Geotech. J. 2015, 52, 1255-1269. [CrossRef]

38. Brown, M.T. Landscape restoration following phosphate mining: 30 years of co-evolution of science, industry and regulation. Ecol. Eng. 2005, 24, 309-329. [CrossRef]

39. Rico, M.; Benito, G.; Salgueiro, A.; Díez-Herrero, A.; Pereira, H. Reported tailings dam failures: A review of the European incidents in the worldwide context. J. Hazard. Mater. 2008, 152, 846-852. [CrossRef]

40. Dixon-Hardy, D.W.; Engels, J.M. Guidelines and recommendations for the safe operation of tailings management facilities. Environ. Eng. Sci. 2007, 24, 625-637. [CrossRef]

41. Rico, M.; Benito, G.; Diez-Herrero, A. Floods from tailings dam failures. J. Hazard. Mater. 2008, 154, 79-87. [CrossRef]

42. Rutherford, P.; Dudas, M.; Arocena, J. Trace elements and fluoride in phosphogypsum leachates. Environ. Technol. 1995, 16, 343-354. [CrossRef]

43. Rutherford, P.; Dudas, M.; Arocena, J. Radon emanation coefficients for phosphogypsum. Health Phys. 1995, 69, 513-520. [CrossRef] [PubMed]

44. Rutherford, P.; Dudas, M.; Samek, R. Environmental impacts of phosphogypsum. Sci. Total Environ. 1994, 149, 1-38. [CrossRef]

45. Reijnders, L. Cleaner phosphogypsum, coal combustion ashes and waste incineration ashes for application in building materials: A review. Build. Environ. 2007, 42, 1036-1042. [CrossRef]

46. Rutherford, P.; Dudas, M.; Arocena, J. Radium in Phosphogypsum Leachates; Wiley Online Library: Hoboken, NJ, USA, 1995.

47. Lèbre, É.; Corder, G.D.; Golev, A. Sustainable practices in the management of mining waste: A focus on the mineral resource. Miner. Eng. 2017, 107, 34-42. [CrossRef]

48. Owen, J.R.; Kemp, D.; Lébre, É.; Svobodova, K.; Murillo, G.P. Catastrophic tailings dam failures and disaster risk disclosure. Int. J. Disaster Risk Reduct. 2020, 42, 101361. [CrossRef]

49. Lèbre, É.; Corder, G. Integrating industrial ecology thinking into the management of mining waste. Resources 2015, 4, 765-786. [CrossRef]

50. Kemp, D.; Owen, J.R.; Lèbre, É. Tailings facility failures in the global mining industry: Will a 'transparency turn' drive change? Bus. Strategy Environ. 2021, 30, 122-134. [CrossRef]

51. Dold, B. Sustainability in metal mining: From exploration, over processing to mine waste management. Rev. Environ. Sci. BioTechnol. 2008, 7, 275-285. [CrossRef]

52. Montoya, T. Yellow water: Rupture and return one year after the Gold King Mine spill. Anthropol. Now 2017, 9, 91-115. [CrossRef]

53. Zhao, Y.; Zang, L.; Li, Z.; Qin, J. Discussion on the Model of Mining Circular Economy. Energy Procedia 2012, 16, 438-443. [CrossRef]

54. Lèbre, É.; Corder, G.; Golev, A. The role of the mining industry in a circular economy: A framework for resource management at the mine site level. J. Ind. Ecol. 2017, 21, 662-672. [CrossRef]

55. Lottermoser, B.G. Recycling, Reuse and Rehabilitation of Mine Wastes. Elements 2011, 7, 404-410. [CrossRef]

56. Van Zyl, D.; Shields, D.; Agioutantis, Z.; Joyce, S. Waste not, want not-rethinking the tailings and mine waste issue. AusIMM Bull. 2016, 38-40.

57. Zafar, Z.I.; Anwar, M.M.; Pritchard, D.W. Innovations in beneficiation technology for low grade phosphate rocks. Nutr. Cycl. Agroecosystems 1996, 46, 135-151. [CrossRef]

58. Koppelaar, R.; Weikard, H. Assessing phosphate rock depletion and phosphorus recycling options. Glob. Environ. Chang. 2013, 23, 1454-1466. [CrossRef]

59. Loutou, M.; Hajjaji, M.; Mansori, M.; Favotto, C.; Hakkou, R. Phosphate sludge: Thermal transformation and use as lightweight aggregate material. J. Environ. Manag. 2013, 130, 354-360. [CrossRef]

60. Zhang, P.; Bogan, M. Recovery of phosphate from Florida beneficiation slimes I. Re-identifying the problem. Miner. Eng. 1995, 8 , 523-534. [CrossRef]

61. Derhy, M.; Taha, Y.; Hakkou, R.; Benzaazoua, M. Review of the Main Factors Affecting the Flotation of Phosphate Ores. Minerals 2020, 10, 1109. [CrossRef]

62. Alsafasfeh, A.; Alagha, L. Recovery of Phosphate Minerals from Plant Tailings Using Direct Froth Flotation. Minerals 2017, 7, 145. [CrossRef] 
63. Oliveira, M.S.; Santana, R.C.; Ataíde, C.H.; Barrozo, M.A.S. Recovery of apatite from flotation tailings. Sep. Purif. Technol. 2011, 79, 79-84. [CrossRef]

64. Testa, F.G. Avanços na Flotação de Finos de Minério com Condicionamento em Alta Intensidade. Master's Thesis, Universidade Federal do Rio Grande do Sul, Porto Alegre, Brazil, 2008.

65. Shang, D.; Geissler, B.; Mew, M.; Satalkina, L.; Zenk, L.; Tulsidas, H.; Barker, L.; El-Yahyaoui, A.; Hussein, A.; Taha, M.; et al. Unconventional uranium in China's phosphate rock: Review and outlook. Renew. Sustain. Energy Rev. 2021, 140, 110740. [CrossRef]

66. Wu, S.; Wang, L.; Zhao, L.; Zhang, P.; El-Shall, H.; Moudgil, B.; Huang, X.; Zhang, L. Recovery of rare earth elements from phosphate rock by hydrometallurgical processes-A critical review. Chem. Eng. J. 2018, 335, 774-800. [CrossRef]

67. Al-Thyabat, S.; Zhang, P. REE extraction from phosphoric acid, phosphoric acid sludge, and phosphogypsum. Miner. Process. Extr. Metall. 2015, 124, 143-150. [CrossRef]

68. Habashi, F. The recovery of the lanthanides from phosphate rock. J. Chem. Technol. Biotech. Chem. Technol. 1985, 35, 5-14. [CrossRef]

69. Jordens, A.; Cheng, Y.P.; Waters, K.E. A review of the beneficiation of rare earth element bearing minerals. Miner. Eng. 2013, 41, 97-114. [CrossRef]

70. Al-Thyabat, S.; Zhang, P. Extraction of rare earth elements from upgraded phosphate flotation tailings. Miner. Metall. Process. 2016, 33, 23-30. [CrossRef]

71. LKAB. LKAB Produces Apatite from Mine Waste in a New Pilot Plant. Available online: https://www.lkabminerals.com/en/ apatite-from-mine-waste-in-new-pilot-plant/ (accessed on 12 October 2021).

72. Leonida, C. Turning Mine Waste from Risk into Opportunity. The Intelligent Miner 2020. Available online: https: // theintelligentminer.com/2020/06/10/turning-mine-waste-from-risk-into-opportunity/(accessed on 30 September 2021).

73. Ettoumi, M.; Jouini, M.; Neculita, C.M.; Bouhlel, S.; Coudert, L.; Taha, Y.; Benzaazoua, M. Characterization of phosphate processing sludge from Tunisian mining basin and its potential valorization in fired bricks making. J. Clean. Prod. 2021, 284, 124750. [CrossRef]

74. OECD. Global Material Resources Outlook to 2060—Economic Drivers and Environmental Consequences; OECD Publishing: Paris, France, 2018.

75. Hakkou, R.; Benzaazoua, M.; Bussière, B. Valorization of phosphate waste rocks and sludge from the Moroccan phosphate mines: Challenges and perspectives. Procedia Eng. 2016, 138, 110-118. [CrossRef]

76. ElIdrissi, H.E.B.; Taha, Y.; Elghali, A.; El Khessaimi, Y.; Aboulayt, A.; Amalik, J.; Hakkou, R.; Benzaazoua, M. Sustainable use of phosphate waste rocks: From characterization to potential applications. Mater. Chem. Phys. 2021, 260, 124119. [CrossRef]

77. Amrani, M.; Taha, Y.; Kchikach, A.; Benzaazoua, M.; Hakkou, R. Valorization of Phosphate Mine Waste Rocks as Materials for Road Construction. Minerals 2019, 9, 237. [CrossRef]

78. Amrani, M.; Taha, Y.; Elghali, A.; Benzaazoua, M.; Kchikach, A.; Hakkou, R. An experimental investigation on collapsible behavior of dry compacted phosphate mine waste rock in road embankment. Transp. Geotech. 2021, 26, 100439. [CrossRef]

79. Amrani, M.; El Haloui, Y.; Hajikarimi, P.; Sehaqui, H.; Hakkou, R.; Barbachi, M.; Taha, Y. Feasibility of using phosphate wastes for enhancing high-temperature rheological characteristics of asphalt binder. J. Mater. Cycles Waste Manag. 2020, 22, $1407-1417$. [CrossRef]

80. Amrani, M.; Taha, Y.; Kchikach, A.; Benzaazoua, M.; Hakkou, R. Phosphogypsum recycling: New horizons for a more sustainable road material application. J. Build. Eng. 2020, 30, 101267. [CrossRef]

81. El Machi, A.; Mabroum, S.; Taha, Y.; Tagnit-Hamou, A.; Benzaazoua, M.; Hakkou, R. Valorization of phosphate mine waste rocks as aggregates for concrete. Mater. Today Proc. 2021, 37, 3840-3846. [CrossRef]

82. El Machi, A.; Mabroum, S.; Taha, Y.; Tagnit-Hamou, A.; Benzaazoua, M.; Hakkou, R. Use of flint from phosphate mine waste rocks as an alternative aggregates for concrete. Constr. Build. Mater. 2021, 271, 121886. [CrossRef]

83. Zheng, K.; Zhou, J.; Gbozee, M. Influences of phosphate tailings on hydration and properties of Portland cement. Constr. Build. Mater. 2015, 98, 593-601. [CrossRef]

84. Bahhou, A.; Taha, Y.; El Khessaimi, Y.; Idrissi, H.; Hakkou, R.; Amalik, J.; Benzaazoua, M. Use of phosphate mine by-products as supplementary cementitious materials. Mater. Today Proc. 2021, 37, 3781-3788. [CrossRef]

85. Bahhou, A.; Taha, Y.; Khessaimi, Y.E.; Hakkou, R.; Tagnit-Hamou, A.; Benzaazoua, M. Using Calcined Marls as Non-Common Supplementary Cementitious Materials-A Critical Review. Minerals 2021, 11, 517. [CrossRef]

86. Bayoussef, A.; Oubani, M.; Loutou, M.; Taha, Y.; Benzaazoua, M.; Manoun, B.; Hakkou, R. Manufacturing of high-performance ceramics using clays by-product from phosphate mines. Mater. Today Proc. 2021, 37, 3994-4000. [CrossRef]

87. Loutou, M.; Taha, Y.; Benzaazoua, M.; Daafi, Y.; Hakkou, R. Valorization of clay by-product from moroccan phosphate mines for the production of fired bricks. J. Clean. Prod. 2019, 229, 169-179. [CrossRef]

88. Bayoussef, A.; Loutou, M.; Taha, Y.; Mansori, M.; Benzaazoua, M.; Manoun, B.; Hakkou, R. Use of clays by-products from phosphate mines for the manufacture of sustainable lightweight aggregates. J. Clean. Prod. 2021, 280, 124361. [CrossRef]

89. Negm, A.; Abouzeid, A. Utilization of solid wastes from phosphate processing plants. Physicochem. Probl. Miner. Process. 2008, 42, 5-16.

90. Yang, Y.; Wei, Z.; Chen, Y.-1.; Li, Y.; Li, X. Utilizing phosphate mine tailings to produce ceramisite. Constr. Build. Mater. 2017, 155, 1081-1090. [CrossRef] 
91. Mabroum, S.; Moukannaa, S.; El Machi, A.; Taha, Y.; Benzaazoua, M.; Hakkou, R. Mine wastes based geopolymers: A critical review. Clean. Eng. Technol. 2020, 1, 100014. [CrossRef]

92. Mabroum, S.; Aboulayt, A.; Taha, Y.; Benzaazoua, M.; Semlal, N.; Hakkou, R. Elaboration of geopolymers based on clays by-products from phosphate mines for construction applications. J. Clean. Prod. 2020, 261, 121317. [CrossRef]

93. Moukannaa, S.; Bagheri, A.; Benzaazoua, M.; Sanjayan, J.; Pownceby, M.; Hakkou, R. Elaboration of alkali activated materials using a non-calcined red clay from phosphate mines amended with fly ash or slag: A structural study. Mater. Chem. Phys. 2020, 256, 123678. [CrossRef]

94. Moukannaa, S.; Loutou, M.; Benzaazoua, M.; Vitola, L.; Alami, J.; Hakkou, R. Recycling of phosphate mine tailings for the production of geopolymers. J. Clean. Prod. 2018, 185, 891-903. [CrossRef]

95. Dabbebi, R.; de Aguiar, J.B.; Camões, A.; Samet, B.; Baklouti, S. Effect of the calcinations temperatures of phosphate washing waste on the structural and mechanical properties of geopolymeric mortar. Constr. Build. Mater. 2018, 185, 489-498. [CrossRef]

96. Ennaciri, Y.; Zdah, I.; El Alaoui-Belghiti, H.; Bettach, M. Characterization and purification of waste phosphogypsum to make it suitable for use in the plaster and the cement industry. Chem. Eng. Commun. 2020, 207, 382-392. [CrossRef]

97. Ennaciri, Y.; Bettach, M. Procedure to convert phosphogypsum waste into valuable products. Mater. Manuf. Process. 2018, 33, 1727-1733. [CrossRef]

98. Rashad, A.M. Phosphogypsum as a construction material. J. Clean. Prod. 2017, 166, 732-743. [CrossRef]

99. Altun, İ.A.; Sert, Y. Utilization of weathered phosphogypsum as set retarder in Portland cement. Cem. Concr. Res. 2004, 34, 677-680. [CrossRef]

100. Singh, M. Treating waste phosphogypsum for cement and plaster manufacture. Cem. Concr. Res. 2002, 32, 1033-1038. [CrossRef]

101. Garg, M.; Jain, N.; Singh, M. Development of alpha plaster from phosphogypsum for cementitious binders. Constr. Build. Mater. 2009, 23, 3138-3143. [CrossRef]

102. Shen, W.; Zhou, M.; Zhao, Q. Study on lime-fly ash-phosphogypsum binder. Constr. Build. Mater. 2007, 21, 1480-1485. [CrossRef]

103. Koopman, C. Purification of Gypsum from Phosphoric Acid Production by Recrystallization with Simultaneous Extraction. Ph.D. Thesis, Technische Universiteit Delft, Delft, The Netherlands, 2003.

104. Cánovas, C.R.; Macías, F.; Pérez-López, R.; Basallote, M.D.; Millán-Becerro, R. Valorization of wastes from the fertilizer industry: Current status and future trends. J. Clean. Prod. 2018, 174, 678-690. [CrossRef]

105. Singh, R.K.; Kumar, A.; Garza-Reyes, J.A.; de Sá, M.M. Managing operations for circular economy in the mining sector: An analysis of barriers intensity. Resour. Policy 2020, 69, 101752. [CrossRef]

106. Sangiorgi, C.; Lantieri, C.; Tataranni, P.; Castro-Gomes, J.; Gabriel, M. Reuse of mining waste into innovative alkali-activated-based materials for road pavement applications. In Functional Pavement Design; CRC Press: Boca Raton, FL, USA, 2016; pp. 1735-1744.

107. Bian, Z.; Miao, X.; Lei, S.; Chen, S.-E.; Wang, W.; Struthers, S. The challenges of reusing mining and mineral-processing wastes. Science 2012, 337, 702-703. [CrossRef] [PubMed]

108. Tayebi-Khorami, M.; Edraki, M.; Corder, G.; Golev, A. Re-thinking mining waste through an integrative approach led by circular economy aspirations. Minerals 2019, 9, 286. [CrossRef]

109. Upadhyay, A.; Laing, T.; Kumar, V.; Dora, M. Exploring barriers and drivers to the implementation of circular economy practices in the mining industry. Resour. Policy 2021, 72, 102037. [CrossRef]

110. Robben, C.; Wotruba, H. Sensor-Based Ore Sorting Technology in Mining-Past, Present and Future. Minerals 2019, 9, 523. [CrossRef] 